UNTAG Law Review (ULREV)

Volume 2, Issue 1, May 2018, PP 85-99

ISSN 2549-4910 (online) \& ISSN 2579-5279 (print)

http://jurnal.untagsmg.ac.id/indeks.php/ulrev/indeks

www.fakhukum.untagsmg.ac.id

\title{
THE MODEL OF OUTSOURCING WORK RELATIONSHIP \\ IN GLOBALIZATION ERA OF LABOR MARKET BASED ON PANCASILA
}

\author{
Mashari
}

Lecturer of Faculty of Law, University 17 August 1945 Semarang

\begin{abstract}
The outsourcing relationship model in the globalization of the labor market based on Pancasila is still reaping controversy among workers and employers. The issue of outsourcing employment relationships in the globalization era of the labor market is a common need among workers, employers and governments. In the implementation of this outsourced employment relationships lead to inconsistency in the element of the employment relationship itself, because workers get orders from employers, whereas employment agreements are made between workers and the Worker Service Company. This inconsistency leads to industrial disputes between outsourced workers and employers. The concept of outsourcing work relations in the era of labor market globalization is a product of liberalism adopted by the Indonesian people when entrepreneurs feel overwhelmed by high labor costs and obliges to provide severance pay, rewards of employment and compensation as regulated in Law Number 13 2003. The implementation of work relations between workers, employers and the government must be in accordance with the souls contained in the precepts of Pancasila, meaning that all forms of behavior of all subjects involved in the process must be based on the noble values of Pancasila as a whole. Outsourcing employment relationship model in the era of labor market globalization based on Pancasila has not run as expected, there are still many problems in the unfinished work of outsourcing industry. The outsourcing work relationship based on Pancasila should make employers and workers no longer across but have the same goal to achieve profit.
\end{abstract}

Keywords : Outsourcing Working Relationship Model, Globalization of Labor Market, Pancasila 


\section{NTRODUCTION}

The State of Indonesia is a legal state must guarantee and enforce the values contained in the Preamble of the 1945 Constitution of the Republic of Indonesia which is a reflection of Pancasila. ${ }^{1}$ In line with Hamid S. Attamimi's view that Pancasila in its position as the legal basis and ideology of the state, it must be a paradigm in the development of the law including all reform efforts in the field of labor law.

One of the most serious employment issues concerning the life of the people is the delivery of some work to other companies, either through employment contracting agreements or the provision of labor services. In simplification and ease of mention, the phrase "the transfer of some work to another company through employment contract or worker / laborer service provider hereinafter referred to as outsourcing.

Outsourcing arrangements in Act No. 13 of 2003 on Manpower, which in Article 64 states that outsourcing is an employment agreement established between employers and workers, in which the company may submit part of the implementation of work to other companies through employment contracts made in writing. In addition, the outsourcing arrangement is regulated in the Decree of the Minister of Manpower and Transmigration of the Republic of Indonesia Number 220 / MEN / X / 2004 concerning Terms of Submission of Part of the Implementation of Work to Other Companies and the Minister of Manpower and Transmigration of the Republic of Indonesia Number 101 / MENNI / 2004 on Procedures of Licensing of Workers / Employers Service Companies.

The arrangement of the outsourced work agreement shall be registered with the Manpower Office, as provided for in Article 64 of Law Number 13 Year 2003 and the Decree of the Minister of Manpower No. 101 of 2004. In relation to these interests, comprehensive and comprehensive arrangements, including the development of resources human resources, productivity improvement, and the competitiveness of Indonesian workers / laborers, employment expansion, worker/labor placement services, and employment counseling aimed at improving the welfare of workers in particular and the welfare of society in general. ${ }^{2}$

Based on data obtained from the Ministry of Manpower of the Republic of Indonesia (RI

1 HR. Ridwan, 2008, Law of State Administration, Grafindo, Jakarta, p. 282.

2 H. Salim, HS, 2008, Contract Design and Memorandum of Understanding, Sinar Grafika, Jakarta, p. 9. 
Ministry of Manpower), the number of Workers / Workers Service (PJP) listed in January 2011 is as many as 4598 companies with the number of outsourced workers reached 255,703 people. ${ }^{3}$ In December 2012, the data increased quite sharply, which is as many as 6,492 companies with the number of outsourced workers reached 335,456 people. Meanwhile, based on a labor survey conducted by the Indonesian National Workers Union (SPNI) in cooperation with the Friedrich Ebert Stiftung ${ }^{4}$ mentions, about 20 million people work under the outsourcing system. ${ }^{5}$ The problems of working relationships applied in general are in the form of a Specific Time Working Agreement (PKWT), wages, social security is limited to a minimum, no job security and no guarantee of career development. ${ }^{6}$

In this working relationship there is no job security because the employment relationship is a contract with an average contract period of 1 (one) year, only get the minimum wage and receive some benefits that are smaller than those received by permanent workers. Things will get worse as workers work in outsourcing companies that set fines for workers who make mistakes.

\section{Formulation of the problem}

Based on the background mentioned above, then the problem can be formulated as follows:

1. Why is there an outsourcing relationship problem in the globalization era?

2. How does the outsourcing relationship coexist in the era of globalization based on Pancasila?

3. How is the outsourcing relationship model in the era of free market globalization based on Pancasila?

\section{Discussion}

\section{Outsourcing Working Relationships In the Era of Globalization}

In general, the term outsourcing is defined as a contract work out as stated in the Concise

3 Data of the Directorate General of Industrial Relations and Social Security of Manpower of Kemenaker R.I. on Recapitulation of Company Data of Workers / Workers and PKWT Provider up to January 27, 2011.

4 Friedrich Ebert Stiftung, Friedrich Ebert Stiftung in Indonesia: Promoting Social Democratization and International Understanding, http://www.fes.or.id/profile.php?lang=2, accessed on March 11, 2015.

5 SPNI and FES Foundation, New Labor Decree Off Course, The Jakarta Post, November 19, 2012, p. 19.

6 Riki Marjono, Criticism Of Implementation Of Outsourcing System In PT. PLN Central JavaDIYDistribution.http://www.lbhyogyakarta.org/2013/08/2371,accessedon February 8, 2015 . 
Oxford Dictionary, while the contract itself is defined as "Contract to enter into or make a contract. From the latin contractus, the past participle of contrahere, to draw together, bring about or enter into an agreement. In the past the covenant activity made the design together, became the basis for approval. ${ }^{7}$ According to Komang Priambada ${ }^{8}$ outsourcing is the outsourcing of some or all of the work and or authority to other parties to support the strategy of outsourced service users, whether personal, company, division, or a unit within the company. Based on Law Number 13 Year 2003 on Article 64, the definition of outsourcing system working relationship can only be done through two forms of written work agreement, namely (1) job vacancy, or (2) workers service provider.

Basically the working relationship between workers and employers occurs after an agreement is made by workers with employers in which workers declare their ability to receive wages and employers declare their ability to hire workers by paying wages.' Based on the provisions of Article 50 of Law Number 13 Year 2003 regarding Manpower, it is explained that the employment relationship occurs because of an employment agreement between employers and workers. ${ }^{10}$ Not all types of work can be made with a specific time work agreement. Article 57 Paragraph (1) of Law Number 13 Year 2003 requires the form of PKWT to be written and has 2 qualifications based on the term and PKWT based on the completion of a certain job.

The implementation of outsourced system work relationships creates a third party in the working relationship between the worker and the company, ie a chartering company or a provider of labor services / laborers. In contrast to outsourcing job vacancies, the type of outsourcing activities of providing workers services is a form of bam in the sense of outsourcing. Types of outsourcing through the provision of labor services are also often referred to as insourcing, ie bringing in laborers from labor-provider companies into the company to do certain work. The employers only provide labor services and take care of human resources and administration only, while facilities such as premises, supervisors, and all production equipment are in the user's company.

7 Nur Cahyo, 2006, Transfer of Work Supporting company with Outsourcing System (Change of Power) According to Law no. 13 year 2003 About Manpower (Case Study on Insurance of Astra Buana), Master of Law Faculty of Law University of Indonesia, Depok.

8 Komang Priambudi, 2008, Outsourcing Versus Unions, Alihdaya Publishing, Jakarta, p. 35.

9 Imam Soepomo, 1999, Introduction to Labor Law, Djambatan, Jakarta, p. 88.

10 F.X. Djulmiaji, 2008, Work Agreement Revised Edition, Sinar Grafika, Jakarta, p. 96. 
The distinction of the type of employment agreement, which is based on certain time employment agreements and time contracts is not certain. A certain time employment agreement (PKWT) is an employment agreement between a worker and an employer to establish a working relationship within a certain time and for a particular job. ${ }^{11}$

In the implementation of the work agreement should be a mutually beneficial relationship and developed the middle ground that both parties realize that they need each other. On the other hand, if the employer provides cheap wages, whereas the company is able to provide higher wages, the worker's morale is decreasing and consequently the production decreases. Therefore, the relations between employers and laborers should be mutually beneficial, but what tends to happen is patron-client work relations, resulting in the emergence of bourgeouis and playwright classes, as Karl Max points out. ${ }^{12}$

According to Bruce E.Kaufmann that although in the United States, industrial relations has been in existence since the late 1920s, there are three debates that occur in labor issues related to industrial relations, one of which is the dependence and weak bargaining position of workers and unions on government regulations (government regulation in the form of protective labor legislation). ${ }^{13}$ According to Araki Takashi, professor of labor law from the University of Tokyo: ${ }^{14}$

"The labor contract is the contract between the labor supplier (user laborer) and user of the labor side. There are many forms, form in written or unwritten, collective or individual, between person to person, between person and company. Also there is the term basis of types. Permanent (or non-fixed terms), temporary (fixed term), daily, part timer type of contract. There is also a type of job contract, labor supply (or labor dispatching) and job undertaking ".

According to the authors that the provisions of the article become legally defective because the elements of the employment agreement are not fully formulated in the formulation of this article. For example, the element of the order, in the outsourcing of workers the element of this order comes from the employer company (not the employer) as well as the wages paid by the employer company (not the employer) through the employer (which is legally the employer of

11 Iftida Yasar, 2009, Designing Outsourcing Working Agreement, PPM Management Jakarta, p. 76.

12 Piotr Sztompka, 2007, Sociology of Social Change, Prenada Media Group, Jakarta.

13 Bruce E. Kaufmann, Government Regulation of the Employment Relationship, New York: Industrial Relations Research Association Series, 1998, 1st. ed.p.2.

14 Araki Takashi, 2013, Roudouhou, Yuuhikaku, Tokyo, p. 47. 
the outsourced workers). In the formulation of the working relationship in the outsourcing of workers, does not meet the elements of employment relationship as defined in Article 1 paragraph 15 of Law Number 13 Year 2003.

The issue of employment relationship is very important to determine who should be responsible if there is Termination of Employment (PHK). During this If there are layoffs, it raises the potential for mutual throwing of responsibilities between employer companies and employment agencies can start from this problem. If until this happens, then the victim is none other than the employees (affected by layoffs) or third parties who are disadvantaged as a result of kelalain in the implementation of work.

\section{The Concept of Outsourced Employment Relationships in the Globalization Era Based on Pancasila}

The basic policy in the labor law is to provide protection to the weak, in this case the workers (labor) to the entrepreneur's entitlement resulting from the process of working relationships with the aim of providing legal protection and realizing social justice. Geoffrey Kay and James Mott assert:

"... the main object of labor law has always been, and I venture to say the will of the bargaining power which is inherent and must be inherent in the employment relationship .... it is an attempt to infuse the law into a relation of command and subordination. "15

According to Agusmidah ${ }^{16}$ in his book "Labor Law Laboratory: Legal Review of Politics," adds that the emergence of labor law is due to the inequalities of bargaining position in labor relations (employers and employers), and based on the exposure it can be seen that the main purpose of the labor law is to be able to eliminate the inequality of the relationship between the parties as far as possible. That is, it can be mentioned that the function of labor law is inseparable from the legal purpose that in general, namely the realization of three basic values of law, justice, benefit and legal certainty.

Peter De Cruz's view ${ }^{17}$ (Comparative Law in Changing Wolrd, 3rd edition in Modern Labor Law section), he says: "Labor law is now focused on the status of the individuals in the

15 Geoffrey Kay and James Mott, 1982, Political Order and The Law of Labor, p. 112.

16 Agusmidah, 2011, Labor Law Labor Law: Review of Political Law, PT. Sofmedia, Jakarta, p. 1-2.

17 Peter de Cruz, 2007, Comparative Law in a Changing World, Routledge \& Cavendish, New York, p. 483. 
employment arena, so that 'status has', to a large extent, supplanted contract, mandatory rule of law replace contractual agreements and administrative regulation and adjudication play an important role (de Vries, 1975). It also includes matters unconnected with the employeremployee nexus, such as social security, legislation, administrative regulation, family allowances, tax privileges, and old-age pension.

In line with what has happened in Indonesia, a policy in the most fundamental aspect of employment is the birth of Law Number 13 Year 2003 on Manpower as an "umbrella" for the rules in other fields of employment. One of the things that the phenomenon of the birth of this Law is the agreement on several things such as concerning freelance workers who are agreed to only be allowed for two years, while for outsourcing workers maximum five years.

According to Muhammad Djumhana that the legal functions that want to give portion to the achievement of welfare, then in labor issues in Indonesia, workers and employers are not seen in terms of different interests. ${ }^{18}$ The role of manpower in a production process determines the end result of production, meaning that labor is not only seen as a means of production but also must get a good and proper treatment so that the welfare of the workers must be considered by both the government and entrepreneurs themselves. It is as stated in Article 28D Paragraph (2) of the 1945 Constitution that: "Everyone shall have the right to work and to receive fair and reasonable remuneration and treatment in the employment relationship."

According to Duclos, ${ }^{19}$ described as 'the equals' in horizontal justice are ethnically equivalent individuals. The principle of horizontal justice is that two ethnically equivalent individuals (having the same level of prosperity) should be treated equally by the state government. Horizontal justice in the field of work, is that workers who have the same job or occupation should be treated equally or no difference in treatment. In relation to outsourcing, horizontal justice sees a relationship between equal workers (equal welfare) in the same sense in their work or in the same position, whether they are outsourced workers or permanent workers.

According to Adam Smith, in fact what is meant by a fair wage does not mean the same wage, just the same in wages is a form of injustice. ${ }^{20}$ In terms of a fair wage is a level of wage which is in Adam Smith's expression, "the lowest of which corresponds to the sense of humanity." That

18 Muhammad Djumhana, 1994, Indonesian Social Economic Law, PT Citra Aditya Bakti, Bandung, p. 239.

19 Jean-Yves Duclos, 2006, Equity and Equality, Université Laval, Département d'économique, Canada, p. 19.

20 See Adam Smith, 2007, The Wealth of Nations, Modern Library, New York, p. 66. 
is to say, what is needed is a minimum level of wage that is still tolerated by humanity, and therefore considered fair. ${ }^{21}$

The concept of outsourcing according to Mason A. Carpenter and Wm. Gerald Sanders, as dikutifAmin Widjaja is: Outsourcing is activity performed for a company by people other than its full-time employees. (Outsourcing is an activity undertaken for an enterprise by persons other than full time employees). In the practice of outsourcing there are three parties that do the working relationship, namely the principal (user companies), the vendor (the recipient company or provider of services workers / labor) and the workers / laborers, where the employment relationship of workers / laborers not with principal companies but with vendor companies.

\section{Outsourcing Working Relationship Model in the Era of Globalization of Labor Market Based on Pancasila}

Entering the current era of globalization ranging from household products to high-tech products even labor exchange and interact. Therefore, Indonesia should implement a system capable of providing competition in the labor market. This system is for example a more efficient bureaucracy and trimming illegal levies. The government must provide various social security, while entrepreneurs are guaranteed and legal certainty to invest. Indonesia should not abandon the character of the nation, if it does not have a strong nation character, it is very easy to accept outside culture without any selection.

Outsourcing as a product of capitalism should also be accepted, with various regulations that can protect Indonesian workers. Market expansion because globalization is not new and this phenomenon arose recently because of the new free market agreement. This free market agreement also includes competition for employment. Therefore outsourcing as a new type of slavery can be minimized. Seeing India succeeded in becoming an outsourcing place, should spur the spirit of various parties ranging from laborers, government, to entrepreneurs. The fact that happened in Indonesia on the contrary as if not ready to compete with workers of other countries.

The employment system is built to realize the implementation of employment relations between workers/laborers, employers and governments must be in accordance with the souls

21 A. Sonny Keraf, 1998, Business Ethics of Demands and Relevance, Canisius Publisher, Yogyakarta, p. 164. 
contained in the precepts of Pancasila, meaning that all forms of behavior of all subjects involved in the process must be based on the noble values of Pancasila as a whole. The concept in the working relationship that governs the actors and the production process based on the noble values in Pancasila has a different approach, because of the values of Pancasila such as the nature of togetherness and mutual cooperation. The working relationship between employers and workers is no longer the opposite but has the same goal to achieve profit based on Pancasila as follows:

The review of the application of the content of the Pancasila precepts, as exemplified, is not unlike the Labor Law found in the positive laws of different countries or those found in international conventions. Based on the content of Pancasila content is not a creation of power for workers to face the economic power of employers, but should be viewed as a form of cooperation from workers. Workers will work together with entrepreneurs creating fair rules in their employment agreements.

The implementation of outsourcing relations based on Pancasila in Indonesia should bring an ideal and peaceful atmosphere in industrial relations. In the practice of working relationship is still far from expectations, this is due among others: Workers and Employers still put themselves in a position that is crossed and do not feel have the same interests. Workers feel that Employers are exploiting them; while employers feel that many workers do not perform their duties properly. Meanwhile, the Government that should be a mediator is considered in favor of the employers.

Outsourcing work relationships based on Pancasila have the noble values of Pancasila which, if applied properly, will have a positive impact on industrial relations. Outsourcing work relationship is considered still not functioning due to various problems arising in the field of industrial relations has not been resolved properly. Efforts to rebuild a working relationship based on Pancasila so that the life of industrial relations in Indonesia can be balanced, fair, and based on deliberations of consensus for a better Indonesian unity in the eyes of Indonesian society especially in the eyes of the world community.

The problem of outsourcing is a crucial problem that not only experienced by Indonesia, but also experienced by other countries such as Japan, England, and the United States. Outsourcing issues include the difference in wages and treatment of workers. For example, the 
problem of job vacancy in Japan has sprouted from the beginning of 1960-1970. The problem is considered to be an obstacle in promoting the Japanese economy both by the government, employers, and workers in Japan at the time. The Japanese government "sits at a table" with employers and workers to resolve labor disputes especially outsourcing disputes without causing conflict. In this case the settlement of labor disputes is prioritized by way of deliberation. $^{22}$

According to the author to fill the void and to overcome the problems of outsourcing, one alternative that can be taken is the application of the doctrine of joint employment or joint employer as conducted in the United States. This joint employment model even though this is not directly related to third party protection, but the solution offered by this doctrine is the way out of who is responsible when there is mutual responsibility.

This joint employer model is actually not contrary to the principle of business actor responsibility as stated in Law Number 8 Year 1999 regarding Consumer Protection. In the context of outsourcing, Law No. 8 of 1999 actually provides a place for joint employment model. The State of Indonesia in practice the employer company has not given a positive side to the implementation of joint employment / joint employer. The authors hope that one day the implementation of this system can provide a positive reference to protect employees and third parties from employers and employers.

\section{CONCLUSION}

Based on the description of the above discussion, it can be concluded as follows:

a. Outsourcing work relationships in the era of globalization are regulated in Article 1 paragraph 15 of Law Number 13 Year 2003 that "employment relationship is a relationship between employers and workers based on employment agreements containing elements of wages, employment and orders that are elements in the work agreement between workers and companies . In an employment outsourcing employment relationship, the employer company may give orders either directly or indirectly to the worker. This working relationship raises the inconsistency of the element of the employment relationship itself, since the worker gets orders from the employer company, while the work agreement is made between the workers and the Worker Service Company.

22 See, Sharoushi Overcome Labor Problems, Voice Updates, November 11, 2013. 
b. The concept of outsourcing employment in the globalization era of the labor market is a product of liberalism adopted by the Indonesian people when employers feel overwhelmed by high labor costs and obliges to provide security for severance pay, rewards of employment, and reimbursement of rights. The concept of a working relationship between the actors and the production process based on noble values in Pancasila has a different approach, because of the values of Pancasila and the 1945 Constitution, such as the nature of togetherness and mutual cooperation. This concept has been set forth in Article 28D paragraph (2) of the 1945 Constitution and Article 27 paragraph (2) states. The concept of a new outsourcing work relationship will be achieved if there is a balance between the workers getting the orders from the employer company created a harmonious working relationship as regulated in Article 1 paragraph (15) of Law Number 13 Year 2003.

c. Outsourcing employment relationship model in the era of labor market globalization based on Pancasila has not run as expected, there are still many problems in the unfinished work of outsourcing industry. The problems of outsourced employment relations are due to several things, such as: (a) Mental Attitudes of the parties in industrial relations; (b) Poor Law Enforcement in Employment Issues; (c) Rules whose substance is not good; and (d) Community Law Culture. It should be the outsourcing work relationship between the actors in the process of producing goods and services based on the noble values of Pancasila and the 1945 Constitution which is the guideline of life of the Indonesian nation.

\section{SUGGESTIONS}

Based on the results of research that has not been answered on the conclusion, it can be suggested as follows:

a. The Government should, through the Ministry of Manpower of the Republic of Indonesia, consistently regulate the working relationship between workers and the Worker Service Company, so as not to trigger industrial disputes between outsourced workers and employers.

b. Employers, Entrepreneurs and Employment Service Providers should be employed as outsourcers in the globalization era to resolve their perspectives based on the noble values of Pancasila, such as the nature of togetherness and mutual cooperation.

c. The Society should in particular understand the working relationship of outsourcing in the era of globalization of the labor market into a common need that needs to be regulated by 
basing the values of Pancasila, thus making employers and workers no longer opposite but having the same goal to achieve profit.

\section{REFERENCES}

\section{Books:}

A. Sonny Keraf, 1998, Business Ethics Demands and Relevance, Kanisius Publishers, Yogyakarta.

Agusmidah, 2011, Labor Law Labor Law: Review of Political Law, PT. Sofmedia, Jakarta.

Adam Smith, 2007, The Wealth of Nations, Modern Library, New York.

Araki Takashi, 2013, Roudouhou, Yuuhikaku, Tokyo.

Bruce E. Kaufmann, Government Regulation of the Employment Relationship, New York: Industrial Relations Research Association Series, 1998, 1st.

Chandra Suwondo, 2003, Outsourcing; Implementation in Indonesia, Elex Media Computindo, Jakarta.

F.X. Djulmiaji, 2008, Work Agreement Revised Edition, Sinar Grafika, Jakarta.

Geoffrey Kay and James Mott, 1982, Political Order and The Law of Labor.

H. Salim, HS, 2008, Contract Design and Memorandum of Understanding, Sinar Grafika, Jakarta.

HP Radjagukguk, Legal Certainty For Outsourcing System Worker, Paper.

HR. Ridwan, 2008, Law of State Administration, Grafindo, Jakarta.

Iftida Yasar, 2009, Designing Outsourcing Working Agreement, PPM Management Jakarta.

Imam Soepomo, 1999, Introduction to Labor Law, Djambatan, Jakarta.

Jean-Yves Duclos, 2006, Equity and Equality, Université Laval, Département d'économique, Canada.

Judge Bartolome' Rios Salmeron, in the General Report of the Social Dialogue Eight Meeting of the European Labor Court Justice, Jerusalem, September 3, 2000.

Komang Priambudi, 2008, Outsourcing Versus Unions, Alihdaya Publishing, Jakarta. 
Muhammad Djumhana, 1994, Indonesian Social Economic Law, PT Citra Aditya Bakti, Bandung.

Nur Cahyo, 2006, Transfer of Work Supporting company with Outsourcing System (Change of Power) According to Law no. 13 year 2003 About Manpower (Case Study on Insurance of Astra Buana), Master of Law Faculty of Law University of Indonesia, Depok.

Peter de Cruz, 2007, Comparative Law in a Changing World, Routledge \& Cavendish, New York.

Piotr Sztompka, 2007, Sociology of Social Change, Prenada Media Group, Jakarta.

\section{Regulation:}

Case of PT Tri Patra Engineer and Contractor, 2002, Workers at PT Tri Patra Engineer and Contractor reject the layoffs against them and request reinstatement in PT Caltex Pacific Indonesia.

Decree of the Minister of Manpower and Transmigration of the Republic of Indonesia Number: Kep.100 / Men / VI / 2004 on Implementation of Working Agreement of Certain Time.

Decree of the Minister of Manpower and Transmigration Number: Kep.201 / Men / 2001 on Representation in Institutional Employment.

Law Number 13 Year 2003 regarding Manpower.

Of the 1945 Constitution of the State of the Republic of Indonesia.

Regulation of the Minister of Manpower of the Republic of Indonesia Number 14 Year 2015 on the Strategic Plan of the Ministry of Manpower Year 2015-2019.

Regulation of the Minister of Manpower and Transmigration of the Republic of Indonesia Number 19 of 2012 concerning Terms of Submission of Part of the Implementation of Work to the Company.

Regulation of the Minister of Manpower and Transmigration No. 19 of 2012 on Terms of Submission of Some Implementation of Work to Other Companies, LN Year 2012 No. 1138. 
Sharoushi Overcome Labor Problems, Voice Updates, November 11, 2013.

SPNI and FES Foundation, New Labor Decree Off Course, The Jakarta Post, November 19, 2012, p. 19.

\section{Internet / Papers:}

Aloysius Uwiyono, Dynamics of Legal Provisions on Severance, http:// www.Hukumonline accessed on December 9, 2007.

In the Preamble to the 1945 Constitution, the fourth paragraph states that: "The state of Indonesia protects all nations and all the blood of Indonesia, promotes the common prosperity, educates the nation and participates in the world order based on independence, eternal peace and social justice based on Pancasila."

In the Labor Relationship in a Changing Environment, London: Cornell University, 1990, Alan Gladstone cites the German Civil Code, 1990, "... the provisions concerning termination of the labor contract."

Data of the Directorate General of Industrial Relations and Social Security of Manpower of the Ministry of Manpower and Transmigration R.I. on Recapitulation of Company Data of Workers / Workers and PKWT Provider up to January 27, 2011.

Friedrich Ebert Stiftung, Friedrich Ebert Stiftung in Indonesia: Promoting Social Democratization and International Understanding, http://www.fes.or.id/ profile.php?lang=2, accessed on March 11, 2015.

Indonesia, Minister of Manpower and Transmigration Regulation no. 19 of 2012 on Terms of Submission of Some Implementation of Employment to Other Companies, op.cit., Article 3 mentioned that in employment, employers may give orders either directly or indirectly to workers.

See Siprianus Edi Hardum, Outsourcing Working System Applies also in Japan, www.beritasatu.com/asia/147584-system-kerja-outsourcing-in-juga-di-japan.html, accessed on 5 June 2015.

According to the Central Bureau of Statistics, Outsourced workers in Indonesia are dominated by low educated people, see Official Gazette No. 35/05 / Th.XVI, 6 
Online: http://michiko60.wordpress.com/2012/02/14/seputar-hukum-contract-commercial. 